\title{
First report on the molecular epidemiology of Malaysian Staphylococcus epidermidis isolated from a University Teaching Hospital
}

\author{
Nurul Azirah Mohamad Sani ${ }^{1}$, Hassriana Fazilla Sapri ${ }^{1}$, Hui-min Neoh ${ }^{2 *}$ and Salasawati Hussin ${ }^{1 *}$
}

\begin{abstract}
Background: Staphylococcus epidermidis is a pathogen associated with nosocomial infections whose medical importance has increased due to progressively invasive medical procedures. In this study, we characterized the molecular epidemiology of S. epidermidis strains circulating in our university hospital situated in Kuala Lumpur, Malaysia.
\end{abstract}

Findings: A total of 798 S. epidermidis were isolated from our university hospital, where $56.3 \%$ of the isolates were found to be cefoxitin (methicillin) resistant and also positive for the mecA gene. Staphylococcus Cassette Chromosome mec (SCCmec) typing revealed that 39.6\% of the methicillin-resistant S. epidermidis (MRSE) were SCCmec-untypeable, with 54.6\% harboring the cassette chromosome recombinase C (ccrC) gene. A total of 67 isolates from the neonatal intensive care unit (NICU) was selected for pulsed-field gel electrophoresis (PFGE) typing, where 13 pulsotypes were identified at a cut-off value of $80 \%$ similarity. No significant association was found between the PFGE pulsotypes, SCCmec types and antibiotic susceptibilities. Polymerase chain reaction (PCR) assays to detect biofilm-associated genes in the ica operon and also 4 staphylococcal toxin genes (cna, seh, PVL genes and $t s t-1)$ revealed that only $8.0 \%$ isolates had the complete operon, while cna was the most prevalent toxin gene detected amongst the isolates (35.8\%).

Conclusion: To our knowledge, this is the first report on the molecular epidemiology of Malaysian S. epidermidis. We found the strains to be low in virulence potential; nevertheless further studies have to be conducted to determine if this phenomenon translates into a better clinical outcome for patients.

Keywords: SCCmec typing, Virulence gene typing, Ica operon characterization, Malaysian S. epidermidis

\section{Findings}

Staphylococcus epidermidis, categorized as coagulasenegative staphylococci (CoNS), are important agents of nosocomial infection as they are human normal flora with abilities to survive in hospital settings and medical devices [1]. Recently, the medical importance of S. epidermidis has continued to rise along with the increase of invasive medical procedures and number of immunecompromised patients [2]. In addition, the phenomenon

\footnotetext{
* Correspondence: hui-min@ppukm.ukm.edu.my; sawati@ppukm.ukm.edu.my ${ }^{2}$ UKM Medical Molecular Biology Institute (UMBI), Universiti Kebangsaan Malaysia, Kuala Lumpur, Malaysia

'Department of Medical Microbiology and Immunology, Faculty of Medicine, Universiti Kebangsaan Malaysia Medical Molecular Biology Institute (UMBI), UKM Medical Centre, Bandar Tun Razak, Cheras, Kuala Lumpur 56000, Malaysia
}

\section{Biomed Central}

(c) 2014 Sani et al.; licensee BioMed Central Ltd. This is an Open Access article distributed under the terms of the Creative Commons Attribution License (http://creativecommons.org/licenses/by/2.0), which permits unrestricted use, distribution, and reproduction in any medium, provided the original work is properly credited. of drug resistance in multi-drug resistant S. epidermidis (MDRSE) as well as methicillin-resistant $S$. epidermidis (MRSE) strains, coupled with the ability of the pathogen for biofilm production lead to complications for the treatment and eradication of $S$. epidermidis infections $[1,2]$. Molecular studies have also identified the presence of staphylococcal toxin genes, such as exotoxins, enterotoxins and the toxic shock syndrome toxin (tst-1) in $S$. epidermidis, elevating the clinical importance of this nosocomial pathogen [3]. As data about the molecular epidemiology of Malaysian CoNS is still lacking and as S. epidermidis is the predominant CoNS species for nosocomial infections [1-3], we initiated a study to characterize the molecular epidemiology of S. epidermidis strains circulating in our university hospital situated in Kuala Lumpur, Malaysia. 
In 2009, a total of 2354 staphylococci infections were recorded in the hospital. The first isolate of each infection (according to the time and date they were received and registered in the hospital diagnostic laboratory) was collected, colony-purified and stocked as strains. From these strains, 1156 (49.1\%) were identified as CoNS via the tube coagulase test, where 798 (69.0\%) strains were later determined as S. epidermidis with PCR using species-specific primers and cycling conditions as described previously [4] . All CoNS infections have been classified as "true" infections and not contaminants by hospital clinical microbiologists via the presence of pus cells in the samples). From medical record review, the $S$. epidermidis infections were found to have occurred in various wards and clinics of the hospital, including eight surgical (12.5\%) and six medical wards $(25.8 \%)$, the adult and neonatal intensive care units (15.0\%), four paediatric wards (4.9\%) and also eight outpatient clinics $(4.2 \%)$. The strains were isolated mainly from blood $(38.1 \%)$, pus $(40.7 \%)$, tracheal aspirates $(3.0 \%)$ and tips (2.6\%).

The study strains were subsequently tested for their susceptibilities towards various antibiotics using the disk diffusion method (Oxoid Microbiology Products, Thermo Fisher Scientific Inc.) according to Clinical Laboratory Standards Institutes (CLSI) recommendations [5]. More than half $(56.3 \%)$ of the tested strains were found to be resistant to cefoxitin $(1 \mu \mathrm{g}), 81.2 \%$ were resistant to penicillin (10 units), while $53.3 \%$ were resistant to erythromycin $(15 \mu \mathrm{g})$. Comparatively, fewer strains were resistant to ciprofloxacin $(5 \mu \mathrm{g})(29.9 \%)$, fusidic acid $(10 \mu \mathrm{g})(30.4 \%)$, gentamicin $(10 \mu \mathrm{g})(36.0 \%)$, mupirocin $(5 \mu \mathrm{g})(24.2 \%)$ and rifampicin $(5 \mu \mathrm{g})(12.9 \%)$. Interestingly, $1.6 \%$ of the strains were resistant to teicoplanin $(30 \mu \mathrm{g})$; nevertheless, all strains were susceptible to vancomycin $(30 \mu \mathrm{g})$. Almost half of the strains $(48.6 \%)$ were multidrug-resistant; the more common drug-resistance combinations were ciprofloxacinerythromycin-gentamicin-oxacillin resistance (3.9\%), ciprofloxacin-erythromycin-fusidic acid-gentamicin-oxacillin

Table $1 \mathrm{SCCmec}$ types of methicillin-resistant S. epidermidis used in this study

\begin{tabular}{lcc}
\hline SCCmec type & Frequency (n) & Percentage (\%) \\
\hline Type I & 4 & 0.9 \\
Type II & 7 & 1.6 \\
Type III & 7 & 1.6 \\
Type IV & 42 & 9.4 \\
Type V & 34 & 7.6 \\
Type VI & 2 & 0.4 \\
Type VIII & 4 & 0.9 \\
Untypeable & 178 & 39.6 \\
New Pattern & 171 & 38.1 \\
Total & 449 & 100 \\
\hline
\end{tabular}

resistance $(2.5 \%)$ and erythromycin-fusidic acid-oxacillin resistance (2.5\%).

Genomic DNA of each strain was then extracted for molecular studies. Firstly, we proceeded to type the staphylococcus cassette chromosome mec (SCCmec) of MRSEs using the protocol from Kondo et al. [6]. All MRSEs were found to harbor the $m e c A$ gene. However, $39.6 \%$ of the MRSE were SCCmec-untypeable; this finding is in line with other reports of high untypeable-SCCmec percentage among MRSEs (30\% - 50\%) [1,7]. A total of 9.4 and $7.6 \%$ of the tested strains were successfully typed as SCCmec type IV and V, respectively; but only $0.9,1.6,1.6$, $0.4,0.9 \%$ of the strains were typeable as SCCmec types I, II, III, VI and VIII, respectively (Table 1). A total of 33 new

Table 2 New combinations of ccr and mecA class leading to the formation of new SCCmec types in S. epidermidis strains used in this study

\begin{tabular}{|c|c|c|}
\hline SCCmec type & ccr/mecA & Percentage, $\%$ \\
\hline New Pattern 1 & CCrA1B1/A & 1.8 \\
\hline New Pattern 2 & CCrA1B1/C & 1.8 \\
\hline New Pattern 3 & $\mathrm{CCrA} 2 \mathrm{~B} 2 / \mathrm{C}$ & 6.4 \\
\hline New Pattern 4 & $C C r A 3 B 3 / B$ & 0.6 \\
\hline New Pattern 5 & $\mathrm{CCrA3B3/C}$ & 1.2 \\
\hline New Pattern 7 & cCrA4B4/C & 1.2 \\
\hline New Pattern 8 & $\operatorname{ccrC} / \mathrm{A}$ & 8.8 \\
\hline New Pattern 9 & $\operatorname{ccrC} / B$ & 9.9 \\
\hline New Pattern 10 & $c C r A 1 B 1+c c r A 3 B 3+c c r C / A$ & 0.6 \\
\hline New Pattern 11 & ccrA1B1 + ccrA4B4/A & 0.6 \\
\hline New Pattern 12 & CCrA1B1 + cCrA4B4/B & 0.6 \\
\hline New Pattern 13 & $C C r A 1 B 1+C C r A 4 B 4+C c r C / B$ & 1.2 \\
\hline New Pattern 15 & $c C r A 1 B 1+c c r A 4 B 4+c c r C / A$ & 1.2 \\
\hline New Pattern 16 & $C C r A 1 B 1+c c r C / B$ & 1.8 \\
\hline New Pattern 17 & $\operatorname{ccrA1B1}+\mathrm{ccrC} / \mathrm{C}$ & 4.1 \\
\hline New Pattern 19 & $C C r A 2 B 2+C C r A 3 B 3+c c r C / A$ & 0.6 \\
\hline New Pattern 20 & $c C r A 2 B 2+c C r A 4 B 4 / A$ & 1.8 \\
\hline New Pattern 21 & $c C r A 2 B 2+c c r A 4 B 4 / B$ & 4.1 \\
\hline New Pattern 22 & $c c r A 2 B 2+c c r A 4 B 4+c c r C / A$ & 1.2 \\
\hline New Pattern 23 & $C C r A 2 B 2+c c r A 4 B 4+c c r C / B$ & 2.9 \\
\hline New Pattern 24 & $C C r A 2 B 2+C C r A 4 B 4+C c r C / C$ & 1.2 \\
\hline New Pattern 25 & $\operatorname{ccr} A 2 B 2+\operatorname{ccr} C / A$ & 2.9 \\
\hline New Pattern 26 & $\operatorname{ccr} A 2 B 2+c c r C / B$ & 26.3 \\
\hline New Pattern 27 & $\operatorname{ccr} A 2 B 2+\mathrm{ccrC} / \mathrm{C}$ & 7.0 \\
\hline New Pattern 29 & $C C r A 2 B 2+C C R A 3 B 3 / B$ & 0.6 \\
\hline New Pattern 30 & $\operatorname{ccr} A 4 B 4+c c r C / A$ & 3.5 \\
\hline New Pattern 31 & $c C r A 4 B 4+c c r C / B$ & 2.3 \\
\hline New Pattern 32 & $\mathrm{ccrA} 4 B 4+\mathrm{ccrC} / \mathrm{C}$ & 3.5 \\
\hline \multirow[t]{2}{*}{ New Pattern 33} & $C C r A 1 B 1+C C r A 2 B 2+C C r A 3 B 3+c c r C / A$ & 0.6 \\
\hline & Total & 100 \\
\hline
\end{tabular}




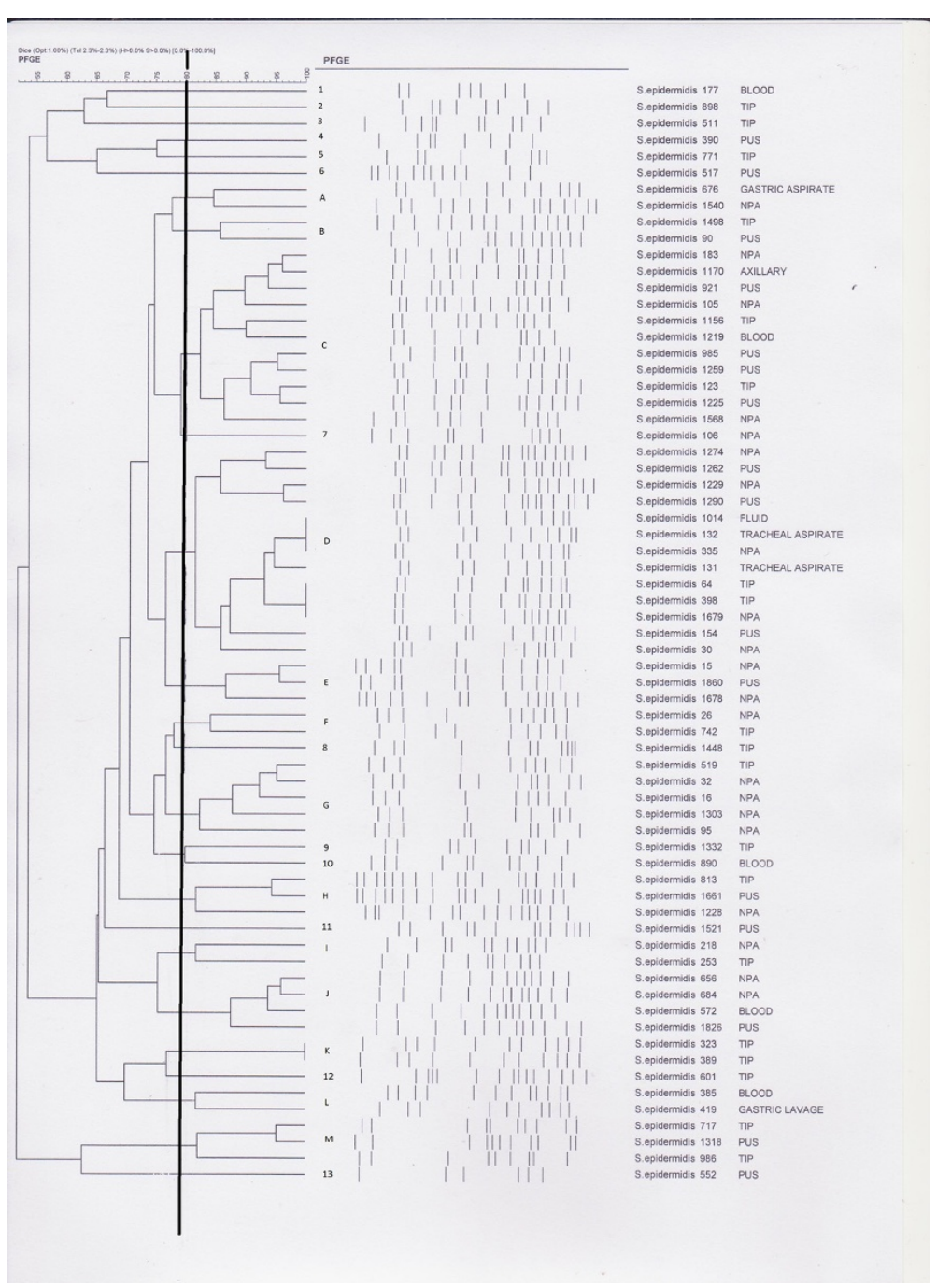

Figure 1 Pulsed-field gel electrophoresis (PFGE) pulsotypes for $67 \mathrm{~S}$. epidermidis strains isolated from the neonatal intensive care unit (NICU). With a $80 \%$ similarity cut-off point, a total of 13 pulsotypes and 13 singletons were identified. Two major pulsotypes, designated as pulsotypes $C$ and D, contained 15 and 11 strains, respectively.

potential SCCmec combinations were found, and 9 out of these 33 combination patterns have been described elsewhere [7]. Interestingly, even though many of the MRSEs were SCCmec-untypeable, a high percentage (54.6\%) were found to harbor the cassette chromosome recombinase $\mathrm{C}$ $(\mathrm{crC})$ gene, either alone or in combination with the other ccr genes, where $c c r A 2 B 2$ was the frequent combination partner (43.2\%) (Table 2). ccrC in SCCmec V was reported to have high transferability among Staphylococcal species and strains [8]. This edge in transferability might be the reason why most $S$. epidermidis in our hospital harbors the $c r r C$. High abundance of $c c r C$ might have also driven the mobility of SCCmec elements in our strains, causing the derivement of new and varied SCCmec types in the species. In addition, Katayama et al. [9] reported that ccrA2B2 elements usually carry macrolide resistance genes; this tallied with our strains' antibiogram where $53.3 \%$ of our CoNS that carried $c c r A 2 B 2$ were also resistant to erythromycin.

As no dominant SCCmec type could be found for our study strains, we attempted to type the strains using Pulsed-Field Gel Electrophoresis (PFGE) to check for a dominant pulsotype in our hospital setting. Due to the large number of S. epidermidis strains available in 2009, only 67 strains from the neonatal intensive care unit (NICU) were selected for PFGE typing, as most of the strains used in this study were isolated from this ward. PFGE was carried out using a protocol as described previously [1]. When the isolates were analyzed at $80 \%$ similarity cut-off point, a total of 13 pulsotypes and 13 singletons were identified, with the 2 major pulsotypes, C and D, containing 15 and 11 strains, respectively (Figure 1). No 
significant association was found between the strains' PFGE pulsotypes, SCCmec types and antibiotic susceptibilities.

Lastly, to better understand the virulence potential of our study strains, we characterized the biofilm-associated ica operon and also determined the presence of 4 staphylococcal toxin genes (cna, seh, PVL genes and tst-1) in these strains, using currently available protocols $[2,10]$. Interestingly, only $7.4 \%$ of the study isolates did not harbor the ica operon, while $8.0 \%$ of the isolates had the complete operon. icaB was the commonly detected ica gene, either singly (12.2\%) or in varied combinations with the other ica genes (40.0\%). Besides icaA and icaD, icaB is also important for proper biofilm formation, as it codes for a deacetylase which maintains the adhesiveness between bacterial cells and biofilm [2]. On the other hand, we also noted a high abundance $(85.1 \%)$ of the insertion sequence IS256 in this operon of our isolates, a phenomenon which was more frequently observed in nosocomial S. epidermidis strains compared to commensal strains [11]. As for staphylococcal toxin gene determination, $62.7 \%$ of the strains did not carry any of the 4 virulence genes determined, while cna (35.8\%) was the most prevalent toxin gene detected in the strains, either singly (19.4\%) or in combination with the other toxin genes of tst-1, seh and PVL genes (cna with tst1, 1.5\%; cna with seh, 7.5\%; cna with PVL genes, $4.5 \%$; cna with seh and tst-1,3.0\%).

To our knowledge, this is the first report about the molecular epidemiology of Malaysian S. epidermidis isolated from a university teaching hospital. The S. epidermidis studied in our investigation had diverse SCCmec elements and were somewhat low in virulence potential in terms of low staphylococcal virulence gene carriage and haboring incomplete ica operons. Nevertheless, it remains to be determined if these findings do translate into a better clinical outcome for the infected patients.

\section{Competing interests}

The authors declare they have no competing interest.

\section{Authors' contributions}

NA carried out the experiments and drafted the manuscript. HF and HM participated in PCR and PFGE. HM and SH participated in design study, coordination and helped to draft the manuscript. All authors read and approved the final manuscript.

\section{Acknowledgement}

This research is supported by UKM Research University Grants UKM-GUP-TKP08-19-067 and UKM-GUP-2011-308.

Received: 25 July 2013 Accepted: 18 August 2014

Published: 3 September 2014

\section{References}

1. Jamaluddin TZMT, Kyoko KA, Ken H, Masahiko T, Longzhu C, Tadashi B, Chie S, Shigeru K, Ito T, Hiramatsu K: Extreme genetic diversity of methicillinresistant Staphylococcus epidermidis strains disseminated among healthy Japanese children. J Clin Microbiol 2008, 46(11):3778-3783.

2. Bernardo DH, Fortino SS, Blanca LM, Leocio PB, Guadalupe MN: Production of icaADBC-encoded polysaccharide intercellular adhesin and therapeutic failure in pediatric patients with staphylococcal devicerelated infections. BCM Infect Dis 2010, 10(68):1-6.

3. Cunha MLRS, Calsolari RAO: Toxigenicity in Staphylococcus with emphasis on coagulase negative staphylococci. In Current Research, Educational Topics and Trends in Applied Microbiology. Edited by Mendez-Vilas A. Brazil: FORMATEX; 2008:778-782.

4. Morot-Bizot SC, Talon R, Leroy S: Development of a multiplex PCR for identification of Staphylococcus genus and four staphylococcal species isolated from food. J Appl Microbiol 2004, 97(5):1087-1094.

5. CLSI: Perfomance standards for antimicrobial susceptibility testing. In CLSI document M100-S19. Wayne, PA: Clinical and Laboratory Institute; 2010.

6. Kondo $\mathrm{Y}$, Ito T, Ma XX, Watanabe S, Barry NK, Jerome E, Hiramatsu K: Combination of multiplex PCRs for staphylococcus cassette chromosome mec type assigment: rapid identification system for mec, ccr and major differences in junkyard regions. Antimicrob Agents Chemother 2007, 50(1):264-274.

7. Ibrahem S, Salmenlinna S, Virolainen A, Kerttula AM, Lyytikainen O, Jagerroos $\mathrm{H}$, Broas M, Jaana W: Carriage of methicillin-resistant staphylococci and their SCCmec types in a long-term-care facility. J Clin Microbiol 2009, 47(1):32-37.

8. Ito T, Ma XX, Takeuchi F, Okuma K, Yuzawa H, Hiramatsu K: Novel type V staphylococcal cassette chromosome mec Driven by a novel cassette chromosome recombinase, ccrC. Antimicrob Agents Chemother 2004, 48(7):2637-2651.

9. Katayama $Y$, Ito T, Hiramatsu K: A new class of genetic element, staphylococcus cassette chromosome mec, encodes methicillin resistance in Staphylococcus aureus. Antimicrob Agents Chemother 2000, 44(6):1549-1555.

10. Ma XX, Ito T, Chongtrakool P, Hiramatsu K: Predominance of clones carrying panton-valentine leukocidin genes among methicillin resistant Staphylococcus aureus strains isolated in Japanese hospitals from 1979 to 1985. J Clin Microbiol 2006, 44(12):4515-4527.

11. Kozitskaya S, Cho SH, Katja D, Reinhard M, Kurt N, Ziebuhr W: The bacterial insertion sequence element IS256 occurs preferentially in nosocomial staphylococcus epidermidis isolates: association with biofilm formation and resistance to aminoglycosides. J Infect Immun 2004, 72(2):1210-1215.

doi:10.1186/1756-0500-7-597

Cite this article as: Sani et al: First report on the molecular epidemiology of Malaysian Staphylococcus epidermidis isolated from a University Teaching Hospital. BMC Research Notes 2014 7:597.

\section{Submit your next manuscript to BioMed Central and take full advantage of:}

- Convenient online submission

- Thorough peer review

- No space constraints or color figure charges

- Immediate publication on acceptance

- Inclusion in PubMed, CAS, Scopus and Google Scholar

- Research which is freely available for redistribution 